\title{
Performance of lettuce in sole cropping and intercropping with green
} manures

\author{
Ana Clarissa A Negrini'; Paulo César T de Melo'; Edmilson José Ambrosano²; Rogério Haruo Sakai; \\ Eliana Aparecida Schammass ${ }^{4}$; Fabrício Rossi $^{1}$ \\ ${ }^{1}$ USP-ESALQ, Dep ${ }^{\text {to }}$ Prod. Vegetal, C. Postal 09, 13418-900 Piracicaba-SP; ${ }^{2}$ APTA-Pólo Regional Centro Sul, C. Postal 28, 13400-970 \\ Piracicaba-SP; ${ }^{3}$ IAC, Pós-graduação, C. Postal 28, 13012-970 Campinas-SP; ${ }^{4}$ APTA-Inst. Zootecnia, $13460-000$ Nova Odessa-SP; \\ negriniac@gmail.com; pctmelo@esalq.usp.br; ambrosano@apta.sp.gov.br; rhsakai@gmail.com; eliana@iz.sp.gov.br; rossi@apta.sp.gov.br
}

\begin{abstract}
The performance of lettuce in sole and intercropped with green manures was assessed under different establishment times. The lettuce fresh and dry weight, number of leaves per plant, diameter and length of head, and fresh and dry weight of green manure were evaluated. The intercropping design was additive and both cash and cover crops were planted in rows. The experimental design was of randomized complete blocks in split plot scheme, with six replicates. The plots represented the green manure sowing days (0, 20, 40 and 60 before transplanting of lettuce), and the sub-plots were assigned by cropping systems (lettuce in sole crop and intercropped with black oat, cowpea or white lupin). Simultaneous planting in the intercropping did not affect the lettuce performance. However, when the green manures were sown before lettuce, they influenced it in a negative way. Among the green manures, cowpea increased biomass and had a higher negative effect on lettuce performance compared to white lupin, which appeared to produce less competition. The sole crop and the intercropping with simultaneous planting of the green manures resulted in a better lettuce performance.
\end{abstract}

Keywords: Avena strigosa, Lactuca sativa, Lupinus albus, Vigna unguiculata, polycultures.

\section{RESUMO}

Desempenho de alface em cultivo solteiro e consorciado com adubos verdes

Foi avaliado o efeito de adubos verdes semeados em diferentes épocas, sobre o desempenho da alface consorciada. Avaliou-se os pesos fresco e seco, número de folhas por planta, diâmetro e comprimento da cabeça da alface. Dos adubos verdes avaliaram-se o peso fresco e seco. O consórcio foi implantado em esquema aditivo e tanto alface quanto os adubos verdes foram plantados em linha. Utilizouse delineamento experimental de blocos ao acaso, com parcelas subdivididas e seis repetições. As parcelas foram representadas pelo tempo de semeadura dos adubos verdes em relação ao transplante da alface $(0,20,40$ e 60 dias) e as subparcelas foram representadas pelos sistemas de cultivo (alface solteira, e alface consorciada com aveia-preta, caupi ou tremoço-branco). O plantio simultâneo não influenciou o desempenho da alface. No entanto, quando os adubos verdes foram semeados antes do estabelecimento do consórcio, estes influenciaram negativamente o desempenho da hortaliça. Entre os adubos verdes, o caupi teve maior biomassa e maior efeito negativo no desempenho da alface do que o tremoço-branco que se mostrou menos competidor. O cultivo solteiro e o cultivo consorciado com plantio simultâneo dos adubos verdes resulta em melhor desempenho da alface.

Palavras-chave: Avena strigosa, Lactuca sativa, Lupinus albus, Vigna unguiculata, policultivos.

\section{(Recebido para publicação em 29 de janeiro de 2008; aceito em 4 de janeiro de 2010) (Received on January 29, 2008; accepted on January 4, 2010)}

$\mathrm{L}$ ettuce cultivation is often intensive and made by small farmers (Costa \& Sala, 2005). To maintain and improve the system's fertility at a low price, low energy cost and high resource use efficiency is a difficult task for agroecological farmers. The use of green manures is an alternative, though this technique normally implies cultivating a non-cash crop during part of the season. In this context, the intercropping of green manures with the cash crop should be an alternative.

White lupin (Lupinus albus) and black oat (Avena strigosa) are successfully cultivated in Southern
Brazil as green manures, cover crops and forage (Costa et al., 1992). Cowpea (Vigna unguiculata) is commonly cultivated as a crop and vegetable in Northeastern Brazil and often cultivated in intercropping in Africa (Fery, 2002). Therefore, the potentialities of intercropping and green manuring together should include benefits from both practices, such as, improve the use of resources (water, land and nutrients); increase soil fertility; transfer of nutrients; soil protection; weed and pest control; biodiversity enhancement, and others (Costa et al., 1992; Liebman \& Dyck, 1993; Trenbath, 1993; Mitchell et al., 2002; Oliveira et al., 2005; Salgado et al., 2006).

Some authors have been reporting the success of intercropping lettuce with other vegetables, such as carrot and peruvian carrot (Negreiros et al., 2002; Vieira et al., 2003). However, intercropping systems can pose serious challenges, such as competition, mainly for light, with negative effects on performance and morphological development of the dominated crop (Cecílio Filho \& May, 2002; Oliveira et al., 2005; Santos et al., 2002; Rezende et al., 2005a). According to Wilson (1988), the advantage of intercropping 
depends on the extent to which species do not compete with one another, and plants grown together frequently do compete, primarily for solar radiation. In terms of competition, besides species, varieties, planting time, planting density, planting date and spatial arrangement of the intercropped system also play an important role.

Intercropping systems involving vegetable crops and green manures are relatively uninvestigated, so limited information about this technique is available. Thus, the goal of this study was to evaluate the agronomic performance of lettuce intercropped with three different green manure species (black oat, cowpea and white lupin) in four different sowing times.

\section{MATERIAL AND METHODS}

The experiment was carried out at the "Polo Regional Centro Sul" from the "Agência Paulista de Tecnologia dos Agronegócios (APTA)" in Piracicaba, São Paulo State, Brazil (22 42 'S, $47^{\circ} 38^{\prime} \mathrm{W}$; altitude $560 \mathrm{~m}$ above sea level) between July and November 2005. The soil on the site is classified as a Pauleudalf, with the following chemical characteristics $(0-20 \mathrm{~cm})$ : medium pH (5.35); low $\mathrm{Al}^{+3}(0.0$ mmolc $\left.\mathrm{dm}^{-3}\right)$; high in organic matter $(34.75 \mathrm{~g}$ $\left.\mathrm{dm}^{-3}\right)$, medium in $\mathrm{K}$ (5.5 mmolc $\left.\mathrm{dm}^{-3}\right)$; medium in $\mathrm{P}$ (25.50 $\left.\mathrm{mg} \mathrm{dm}^{-3}\right)$; high SB (85.8); high in $\mathrm{Ca}\left(55.25 \mathrm{mmolc}^{-3}\right)$; high in $\mathrm{Mg}$ (25.0 mmolc $\left.\mathrm{dm}^{-3}\right)$; low in $\mathrm{S}$ (3.75 mmolc $\left.\mathrm{dm}^{-3}\right)$; medium in $\mathrm{Cu}$ $\left(4.5 \mathrm{mg} \mathrm{dm}^{-3}\right)$; medium in B $(0.42 \mathrm{mg}$ $\left.\mathrm{dm}^{-3}\right)$; high in Fe $\left(51.0 \mathrm{mg} \mathrm{dm}^{-3}\right)$; high in $\mathrm{Zn}\left(3.1 \mathrm{mg} \mathrm{dm}^{-3}\right)$; and high in $\mathrm{Mn}$ $\left(45.0 \mathrm{mg} \mathrm{dm}^{-3}\right)$. Total rainfall during the experimental period was $436 \mathrm{~mm}$ and temperature ranged from minimum $11.4^{\circ} \mathrm{C}$ to maximum $30.4^{\circ} \mathrm{C}$.

The species used in the study were lettuce (Lactuca sativa) cv. PiraRoxa, black oat (Avena strigosa), cowpea (Vigna unguiculata) cv. IPA-206 and white lupin (Lupinus albus). The experimental design was randomized complete blocks in split plot scheme, with six replicates, where plots represented the green manures sowing days $(0$, 20, 40 and 60 before transplanting of lettuce), and the sub-plots, which measured $1.80 \times 1.2 \mathrm{~m}$, were represented by the cropping systems (lettuce in sole crop and intercropped with black oat, cowpea or white lupin).

Field plots were established on July 22, 2005, when the first green manures were sown (60 days before lettuce transplanting). Lettuce seedlings were sown in polyethylene trays and after 28 days transplanted to the field plots. Lettuce was planted with a spacing of $0.30 \times 0.30 \mathrm{~m}$ and the green manures were sown in rows spaced $0.30 \mathrm{~m}$ of each other with sowing densities of 68 seeds $\mathrm{m}^{-1}$ for black oat (1.5 cm apart), 15 seeds $\mathrm{m}^{-1}$ for cowpea (6.6 cm apart) and 15 seeds $\mathrm{m}^{-1}$ for white lupin $(6.6 \mathrm{~cm}$ apart). The intercroppings were planted with lettuce in alternate rows between the green manures. Sowing densities were 68 seeds $\mathrm{m}^{-1}$ for black oat $(1.5 \mathrm{~cm}$ apart), 15 seeds $\mathrm{m}^{-1}$ for cowpea $(6.6 \mathrm{~cm}$ apart) and 15 seeds $\mathrm{m}^{-1}$ for white lupin $(6.6 \mathrm{~cm}$ apart) and the rows were also spaced in $0.30 \mathrm{~m}$.

To avoid shading of lettuce plants and consequently sunlight competition, which according to Portes (1984) is the main biotic factor in intercropping systems, the green manures were periodically moved at $0.20 \mathrm{~m}$ above soil. The moved fresh mass was weighed and $10 \%$ of this material was dried in a forced-air oven at $65^{\circ} \mathrm{C}$ for $72 \mathrm{~h}$ for dry weight determination. The remaining fresh mass was laid on the soil surface as mulching. The only green manure plots that were moved before the lettuce transplanting were the 60 DBT treatments (sown 60 days before), to avoid excessive shading of the vegetable seedlings by the green manure's huge amount of biomass.

Automatic drip irrigation was used twice a day before the lettuce transplant (for irrigating the 20, 40 and 60 DBT treatments) and three times a day after the transplant for the rest of the growth cycle. The experimental area was weeded periodically. There was no other fertilizer application besides the green manures mulching.

Lettuce plants were harvested 49 days after transplanting at September 2005. Four central lettuce plants were harvested per plot. The measured parameters were fresh weight, dry weight, number of leaves per plant, diameter and height of head. Of the four lettuce plants harvested, two of them were dried in a forced-air oven at $65^{\circ} \mathrm{C}$ for $72 \mathrm{~h}$ for dry weight determination. The parameters measured in green manures were fresh and dry weight (this measurement was done after each moving).

Statistical analyses were performed using "Sanest" (Zonta et al., 1986) and treatment means were compared by Tukey test $(p<0.05)$. Response curves were fitted to the parameters in function of the green manures sowing dates.

\section{RESULTS AND DISCUSSION}

The fresh and dry mass of the aboveground portion of green manures varied significantly among species. Cowpea produced a significantly higher fresh and dry mass than black oat and white lupin. The fresh and dry weight of green manures species changed significantly depending on the intercropping planting time. A quadratic effect was observed $(p>0.01)$ of black oat on fresh weight $(\hat{\mathrm{Y}}=9.53+1.6056 \mathrm{x}$ $\left.-0.016023 x^{2} ; R^{2}=1.00\right)$. There was a linear effect $(p<0.01)$ of white lupin sowing dates on fresh weight $(\hat{Y}=14.29$ $\left.+0.7962 \mathrm{x} ; \mathrm{R}^{2}=0.95\right)$ and cowpea $(\hat{\mathrm{Y}}$ $\left.=32.86+1.1516 \mathrm{x} ; \mathrm{R}^{2}=0.97\right)$. There was a quadratic effect $(\mathrm{p}<0.05)$ of black oat on dry mass $(\hat{\mathrm{Y}}=5.43+0.4072 \mathrm{x}-$ $0.002587 x^{2}\left[; R^{2}=0.99\right)$, sowing time with the maximum estimated at $79 \mathrm{DBT}$. A linear effect was observed $(p<0.01)(\hat{Y}$ $\left.=5.30+0.2823 \mathrm{x} ; \mathrm{R}^{2}=0.95\right)$ of white lupin and $\left(\hat{\mathrm{Y}}=11.68+0.3991 \mathrm{x} ; \mathrm{R}^{2}=\right.$ 0.97), of cowpea.

These green manures biomass influenced the lettuce fresh yield which varied according to the associated green manure and its sowing time (Table 1). Under simultaneous intercropping planting the average fresh weight of lettuce head was $182.98 \mathrm{~g}$, which suggests that the competition between the component crops was not evident or was rather very weak because there was no difference between the sole crop and the intercroppings. However, when planting was not done simultaneously the intercropped lettuce reached a lower fresh yield compared to the sole 
Table 1. Lettuce fresh and dry weight in sole crop and intercropped with green manures (peso fresco e seco de alface em cultivo solteiro e consorciada com adubos verdes). Piracicaba, ESALQ, 2005.

\begin{tabular}{|c|c|c|c|c|c|}
\hline $\begin{array}{c}\text { Days before transplant } \\
(\text { DBT) }\end{array}$ & $\begin{array}{c}\text { Lettuce } \\
\text { sole crop }\end{array}$ & $\begin{array}{c}\text { Lettuce and } \\
\text { black oat }\end{array}$ & $\begin{array}{l}\text { Lettuce and } \\
\text { white lupin }\end{array}$ & $\begin{array}{c}\text { Lettuce and } \\
\text { cowpea }\end{array}$ & Mean \\
\hline & \multicolumn{5}{|c|}{ fresh weight $\left(\right.$ g plant $\left.^{-1}\right)$} \\
\hline 0 & $194.51 \mathrm{a}$ & $199.59 \mathrm{a}$ & $180.15 \mathrm{a}$ & $157.76 \mathrm{a}$ & 182.98 \\
\hline 20 & $216.87 \mathrm{a}$ & $139.87 \mathrm{~b}$ & $161.95 \mathrm{~b}$ & $137.31 \mathrm{~b}$ & 164.00 \\
\hline 40 & $209.66 \mathrm{a}$ & $106.67 \mathrm{c}$ & $164.17 \mathrm{~b}$ & $92.96 \mathrm{c}$ & 143.37 \\
\hline 60 & $222.54 \mathrm{a}$ & $164.12 \mathrm{~b}$ & $149.62 \mathrm{~b}$ & $148.03 \mathrm{~b}$ & 171.08 \\
\hline Mean & 210.89 & 152.55 & 163.97 & 134.01 & \\
\hline$\overline{\mathrm{CV} \%(\mathrm{a})}$ & 16.70 & & & & \\
\hline CV\%(b) & 17.96 & & & & \\
\hline \multicolumn{6}{|l|}{$\overline{F^{1}}$} \\
\hline Linear effect & ns & ns & ns & ns & \\
\hline Quadratic effect & ns & $*$ & ns & ns & \\
\hline \multirow[t]{2}{*}{ Cubic effect } & ns & ns & ns & ns & \\
\hline & \multicolumn{5}{|c|}{ dry weight (g plant $\left.{ }^{-1}\right)$} \\
\hline 0 & 12.49 & 10.54 & 10.03 & 8.72 & 10.45 \\
\hline 20 & 11.78 & 7.92 & 9.29 & 7.50 & 9.12 \\
\hline 40 & 11.29 & 6.68 & 9.13 & 5.36 & 8.11 \\
\hline 60 & 12.87 & 8.33 & 8.72 & 8.36 & 9.57 \\
\hline Mean & $12.11 \mathrm{a}$ & $8.37 \mathrm{bc}$ & $9.29 \mathrm{~b}$ & $7.48 \mathrm{c}$ & \\
\hline$\overline{C V \%(a)}$ & 11.64 & & & & \\
\hline CV\%(b) & 16.30 & & & & \\
\hline \multicolumn{6}{|l|}{$\mathrm{F}^{1}$} \\
\hline Linear effect & ---- & ---- & ---- & ns & \\
\hline Quadratic effect & ---- & ---- & ---- & $* *$ & \\
\hline Cubic effect & ns & ns & $\mathrm{ns}$ & ns & \\
\hline
\end{tabular}

Means followed by the same letters in rows are not significantly different $(\mathrm{p}>0.05)$ by Tukey test; ${ }^{1} \mathrm{~F}^{*}=(\mathrm{p}<0.05) ;{ }^{* *}=(\mathrm{p}<0.01) ; \mathrm{ns}=\mathrm{not}$

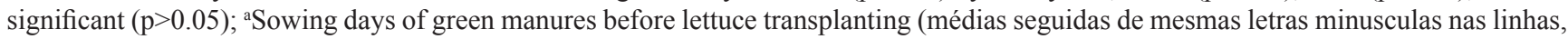

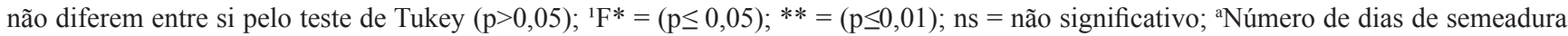
dos adubos verdes antes do transplante das alfaces).

vegetables. Under 20 and 60 DBT there were no significant differences in lettuce fresh weight between the different species of green manures. However, in the 40 DBT treatment, the different green manures species had different effects in the main crop. The lettuce plants intercropped with white lupin had a smaller decrease of fresh mass $(26 \%)$ compared to the ones intercropped with cowpea (58\%) and black oat (42\%). These results are consistent with a similar study made by Hussain (2003) who reported that lettuce intercropped with peas had a $68.4 \%$ yield loss compared to the single crop. According to Muller-Sumann (1994), yield decreases are expected when green manures are intercropped with the food crop.
Lettuce fresh weight showed a quadratic response $(\mathrm{p}<0.05)$ to black oat sowing dates $(\hat{Y}=202.73-5.0882 x+$ $0.073188 \mathrm{x}^{2} ; \mathrm{R}^{2}=0.95$ ), with minimum value of production estimated at $35 \mathrm{DBT}$. The probable reason for this behavior is that the 40 DBT treatments were the most competitive in the early stages of the lettuce development because its biomass was not moved before the transplant of the vegetable seedlings like in the 60 DBT treatment. Thus, this treatment resulted in more shade and consequently more competition between crops.

In terms of dry weight, as well as for fresh weight, the single lettuces performed better (Table 1). Among the green manure treatments were found only differences between lettuce intercropped with white lupin and cowpea, which yielded $77 \%$ and $62 \%$ of the single ones, respectively. There was a quadratic response $(\mathrm{p}<0.01)$ of lettuce dry yield regarding the cowpea sowing dates $\left(\hat{\mathrm{Y}}=10.55-0.1224 \mathrm{x}+0.001737 \mathrm{x}^{2}\right.$; $\mathrm{R}^{2}=0.92$ ), with the minimum yield estimated at 35 DBT as well, showing a higher level of competition related to the 40 DBT treatment. Cowpea is a fast growing plant and a good competitor as observed by Ofori \& Gamedoagbao (2005). In fact, cowpea planting time relative to the associated crop has been reported to be important to cotton, millet, cassava and scarlet eggplant (Ofori \& Gamedoagbao, 2005).

As observed in the present experiment, Sudo et al. (1997) found that there was no yield penalty when lettuce was 
Table 2. Number of leaves per plant, diameter and length of lettuce head in sole crop and intercropped with green manures (número de folhas por planta, diâmetro e comprimento da cabeça de alface em cultivo solteiro e consorciada com adubos verdes). Piracicaba, ESALQ, 2005.

\begin{tabular}{|c|c|c|c|c|c|}
\hline $\begin{array}{c}\text { Days before transplant } \\
(\text { DBT) } \\
\end{array}$ & $\begin{array}{l}\text { Lettuce } \\
\text { sole crop }\end{array}$ & $\begin{array}{c}\text { Lettuce and } \\
\text { black oat }\end{array}$ & $\begin{array}{l}\text { Lettuce and } \\
\text { white lupin }\end{array}$ & $\begin{array}{c}\text { Lettuce and } \\
\text { cowpea } \\
\end{array}$ & Mean \\
\hline & \multicolumn{5}{|c|}{ number of leaves per plant } \\
\hline 0 & $27.83 \mathrm{a}$ & $28.29 \mathrm{a}$ & $26.00 \mathrm{ab}$ & $23.62 \mathrm{~b}$ & 26.44 \\
\hline 20 & $27.58 \mathrm{a}$ & $21.21 \mathrm{bc}$ & $23.25 \mathrm{~b}$ & $19.21 \mathrm{c}$ & 22.81 \\
\hline 40 & $28.21 \mathrm{a}$ & $18.32 \mathrm{c}$ & $22.92 \mathrm{~b}$ & $16.83 \mathrm{c}$ & 21.57 \\
\hline 60 & $29.04 \mathrm{a}$ & $23.17 \mathrm{~b}$ & $22.75 b$ & $20.67 \mathrm{~b}$ & 23.91 \\
\hline Mean & 28.17 & 22.75 & 23.73 & 20.08 & \\
\hline CV\%(a) & 8.07 & & & & \\
\hline CV\%(b) & 9.28 & & & & \\
\hline
\end{tabular}

$\mathrm{F}^{1}$

$\begin{array}{llllr}\text { Linear effect } & \mathrm{ns} & * & \mathrm{~ns} & \mathrm{~ns} \\ \text { Quadratic effect } & \mathrm{ns} & * * & \mathrm{~ns} & * \\ \text { Cubic effect } & \mathrm{ns} & \mathrm{ns} & \mathrm{ns} & \mathrm{ns}\end{array}$

\begin{tabular}{|c|c|c|c|c|c|}
\hline \multirow[t]{2}{*}{ Cubic effect } & ns & $\mathrm{ns}$ & ns & ns & \\
\hline & \multicolumn{5}{|c|}{ diameter of head $(\mathrm{cm})$} \\
\hline 0 & $24.77 \mathrm{a}$ & $24.95 \mathrm{a}$ & $26.06 \mathrm{a}$ & $25.02 \mathrm{a}$ & 25.20 \\
\hline 20 & $26.64 \mathrm{a}$ & $24.58 \mathrm{ab}$ & $24.27 \mathrm{ab}$ & $24.10 \mathrm{~b}$ & 24.90 \\
\hline 40 & $25.48 \mathrm{a}$ & $24.77 \mathrm{ab}$ & $22.64 \mathrm{bc}$ & $21.82 \mathrm{c}$ & 23.68 \\
\hline 60 & $25.43 \mathrm{a}$ & $25.12 \mathrm{a}$ & $24.25 \mathrm{a}$ & $24.91 \mathrm{a}$ & 24.93 \\
\hline Mean & 25.58 & 24.33 & 24.84 & 23.96 & \\
\hline$\overline{\mathrm{CV} \% \text { (a) }}$ & 4.68 & & & & \\
\hline $\mathrm{CV} \%$ (b) & 6.83 & & & & \\
\hline \multicolumn{6}{|l|}{$\mathrm{F}^{1}$} \\
\hline Linear effect & ns & ns & ns & ns & \\
\hline Quadratic effect & ns & ns & ns & $*$ & \\
\hline \multirow[t]{2}{*}{ Cubic effect } & ns & ns & $\mathrm{ns}$ & ns & \\
\hline & \multicolumn{5}{|c|}{ length of head $(\mathrm{cm})$} \\
\hline 0 & $18.29 \mathrm{ab}$ & $19.33 \mathrm{a}$ & $19.00 \mathrm{ab}$ & $17.60 \mathrm{~b}$ & 18.55 \\
\hline 20 & $18.77 \mathrm{a}$ & $17.12 \mathrm{~b}$ & $17.14 \mathrm{~b}$ & $16.79 \mathrm{~b}$ & 17.46 \\
\hline 40 & $18.25 \mathrm{a}$ & $16.21 \mathrm{bc}$ & $16.98 \mathrm{ab}$ & $14.96 \mathrm{c}$ & 16.60 \\
\hline 60 & $18.89 \mathrm{a}$ & $18.17 \mathrm{ab}$ & $17.56 \mathrm{ab}$ & $16.87 \mathrm{~b}$ & 17.87 \\
\hline Mean & 18.55 & 17.71 & 17.67 & 16.55 & \\
\hline$\overline{C V \%(a)}$ & 6.23 & & & & \\
\hline CV\%(b) & 5.60 & & & & \\
\hline
\end{tabular}

$\mathrm{F}^{1}$

\begin{tabular}{|c|c|c|c|c|}
\hline Linear Effect & ns & ns & ns & ns \\
\hline Quadratic Effect & ns & $*$ & ns & ns \\
\hline Cubic Effect & ns & ns & ns & $\mathrm{ns}$ \\
\hline
\end{tabular}

Means followed by the same letters in rows are not significantly different $(\mathrm{p}>0.05)$ by Tukey test; ${ }^{1} \mathrm{~F}^{*}=(\mathrm{p}<0.05) ;{ }^{* *}=(\mathrm{p}<0.01) ; \mathrm{ns}=\mathrm{not}$

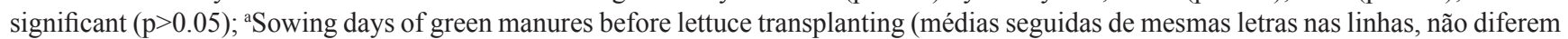
entre si pelo teste de Tukey $(\mathrm{p}>0,05) ;{ }^{1} \mathrm{~F}^{*}=(\mathrm{p} \leq 0,05) ; * *=(\mathrm{p} \leq 0,01) ; n s=$ não significativo; ${ }^{2}$ Dias de semeadura dos adubos verdes antes do transplante das alfaces).

intercropped with carrot in simultaneous planting. These intercropping schemes are probably successful due to the canopy height and accumulated biomass of the green manures, which were not enough to offer competition to the vegetable crops. The establishment time of the intercropping has been shown to influence the companion crops performance (Cecílio Filho et al., 2008; Rezende et al., 2005a). In a tomato/lettuce intercropping at different transplanting dates, when lettuce transplanting was late, both fresh and dry mass and also the number of leaves 
were lower due to light competition between the companion crops. Paula (2005) reported the same result for an onion/lettuce intercropping.

The number of leaves decreased even at simultaneous planting in the intercropping with cowpea (Table 2). For the other sowing times $(20,40$ and 60 DBT) the sole crop resulted in greater number of lettuce leaves compared to all intercropping treatments. The number of leaves goes along with lettuce development, thus observing the lettuce fresh weight at simultaneous planting $(0$ DBT treatment) (Table 1), even though the results are statistically similar, the yield under cowpea influence was lower. Thus a plausible reason for the lower number of leaves in lettuce intercropped with cowpea even at simultaneous sowing, is the competition effect due to the green manure biomass that probably caused shade and competed for light. There was a quadratic effect $(p<0.01)$ of black oat sowing time on lettuce number of leaves $(\hat{\mathrm{Y}}=28.47-0.5381 \mathrm{x}$ $+0.007447 \mathrm{x}^{2} ; \mathrm{R}^{2}=0.99$ ) with minimum number of leaves production estimated when black oat was sown at 36 DBT of lettuce, and for cowpea $(\mathrm{p}<0.05)(\hat{\mathrm{Y}}$ $=23.83-0.3656 \mathrm{x}+0.005156 \mathrm{x}^{2} ; \mathrm{R}^{2}=$ $0.96)$ the minimum was estimated in 35 DBT. This quadratic effect indicates that the 40 DBT treatment posed the greatest level of competition among plants, with consequent shading of lettuce that resulted in a decrease in the number of leaves. This effect tended to decrease as the green manures sowing time changed to 0,20 and $60 \mathrm{DBT}$, resulting in a higher number of leaves per head of lettuce.

According to Sala \& Costa (2005), lettuce cv. PiraRoxa has around 28 leaves at the harvest time, which is supposed to occur between 35 and 45 days after transplanting. At the harvest time of this experiment, only the single lettuces had reached an average of 28.17 leaves per head (Table 2). Thus it is possible to deduce that lettuce plants suffered an extension of their cropping cycles due to an intercropping competition effect, with exception of the simultaneous planting with black oat and white lupin.

The intercroppings established at 0 and 60 DBT did not affect the diameter of head (Table 2). However, the lettuces intercropped with cowpea presented $90 \%$ of the diameter of the sole crop in the 20 DBT treatment and 89 and $86 \%$, respectively to white lupin and cowpea in the 40 DBT treatment. There was a quadratic effect $(p<0.05)$ of cowpea sowing dates on lettuce diameter $(\hat{\mathrm{Y}}$ $=25.35-0.1631 \mathrm{x}+0.002503 \mathrm{x}^{2} ; \mathrm{R}^{2}$ $=0.65)$ (Table 2 ) with the minimum diameter of head estimated at 33 DBT.

In close agreement with this study, Cecílio Filho et al. (2008) and Negreiros et al. (2002) observed that in a lettuce/ tomato and lettuce/carrot intercropping there was a diameter decrease and fewer leaves compared to the sole lettuce cultivation due to sunlight competition imposed by the companion plants. Rezende et al. (2006) also found that the companion species interfere differently in the number of leaves and diameter reached by lettuce. In their case, cabbage influenced negatively and rocket did not.

The length of lettuce head in response to intercropped green manures species changed significantly depending on the intercropping planting time (Table 2). A quadratic effect was observed $(\mathrm{p}<0.05)(\hat{\mathrm{Y}}=19.14-0.1785 \mathrm{x}+$ $\left.0.002610 \mathrm{x}^{2} ; \mathrm{R}^{2}=0.98\right)$, of black oat sowing time with the minimum length of lettuce heads estimated at 35 DBT. In accordance with this, Cecílio Filho \& May (2002) reported that there was a reduction in radish plants height when intercropped with lettuce. On the other hand, in the present experiment lettuce was dominated by the green manures, having its morphological characteristics depreciated.

White lupin is an erect plant and offers much less competition to a companion crop than black oat and cowpea cv. IPA 206 (which is prostrated) because there is more sunlight penetration through its branches. Plant architecture is an important consideration to maximize sunlight utilization in intercropping. In this way, the results obtained for lettuce/ white lupin intercropping agree with a previous experiment done by Ofori \& Gamedoagbao (2005), who tested an erect and a semi-spreading variety of cowpea in intercropping with scarlet eggplant. Similar to the present study, the authors found that the erect green manure offered less competition to the vegetable, which obtained a better performance.

There were neither nutritional deficiency nor drought stress symptoms on the lettuce plants under the different treatments, thus it is assumed that the main source of competition was sunlight. In fact, cv. PiraRoxa depends on light to develop its hallmark purple color and, once it grows under shade, it tends to present greenish leaf coloration. The lettuces under intense intercropping competition in this study showed greenish leaves due to lack of sunlight. However, within 3 days of moving the green manures with the consequent decrease of shade, the leaves of lettuce reverted to its characteristic purple.

In this intercropping system, except for the simultaneous planting, for most analyzed parameters the growing cycle overlapped, causing competition between crops and domination of lettuce by the green manures, which are taller and, consequently, intercept more sunlight. In this way, under the conditions of this experiment, a better performance of lettuce would be obtained under sole cultivation or under intercropping with simultaneous planting of the main crop and the green manures.

\section{ACKNOWLEDGEMENTS}

To Capes (Coordenação de Aperfeiçoamento de Pessoal de Nível Superior) for financial support and Dr. Tony Fischer and Agustín Zsögön for useful comments on the draft manuscript.

\section{REFERENCES}

BARROS JUNIOR AP; BEZERRA NETO F; NEGREIROS MZ; OLIVEIRA EQ; SILVEIRA LM; CÂMARA MJT. 2005. Desempenho agronômico do bicultivo da alface em sistemas consorciados com cenoura em faixa sob diferentes densidades populacionais. Horticultura Brasileira 23: 712-717.

CECÍLIO FILHO AB; REZENDE BLA; BARBOSA JC; FELTRIM AL; SILVA GS; GRANGEIRO LCG. 2008. Interação entre alface e tomateiro consorciados em ambiente 
protegido em diferentes épocas. Horticultura Brasileira 26: 158-164.

CECÍLIOFILHOAB; MAYA. 2002. Produtividade das culturas de alface e rabanete em função da época de estabelecimento do consórcio. Horticultura Brasileira 20: 501-504.

COSTA BB (ed). 1992. Adubação verde no sul do Brasil. Rio de Janeiro: AS-PTA. 346 p.

COSTA CP; SALA FC. 2005. A evolução da alfacicultura brasileira. Horticultura Brasileira 23: artigo de capa.

FERY RL. 2002. New Opportunities in Vigna. In: JANIK J; WHIPKEY A (ed.). Trends in new crops and new uses. Alexandria: ASHS Press. p. 424-428.

HUSSAIN SA. 2003. Growth, Yield and Economic Impacts of Intercropping in Vegetables. Peshawar, Pakistan: NWFP Agricultural University. 65 p. (Doctoral thesis).

LIEBMAN M; DYCK E. 1993. Weed management. Ecological applications 3: 40-41.

MITCHELL CE; TILMAN D; GROTH JV. 2002. Effects of grassland plant species diversity, abundance, and composition on foliar fungal disease. Ecology 83: 1713-1726.

MULLER-SÄMANN KM; KOTSCHI; J. 1994. Sustaining growth: soil fertilizer management in tropical smallholdings. Weikersheim: Margraf Verlag. 486p.

NEGREIROS MZ; BEZERRA NETO F; PORTO VCN; SANTOS RHS. 2002. Cultivares de alface em sistema solteiro e consorciado com cenoura em Mossoró. Horticultura Brasileira 20: $162-166$.

OFORI K; GAMEDOAGBAO DK. 2005. Yield of scarlet eggplant (Solanum aethiopicum L.) as influenced by planting date of companion cowpea. Scientia Horticulturae 105: $305-$ 312.

OLIVEIRA EQ; BEZERRA NETO F;
NEGREIROS MZ; BARROS JUNIOR AP; KALLIANY K; FREITAS C; SILVEIRA LM; LIMA JSS. 2005. Produção e valor agroeconômico no consórcio entre cultivares de coentro e de alface. Horticultura Brasileira 23:285-289.

OLIVEIRA FL; RIBAS RGT; JUNQUEIRA RM; PADOVAN MP; GUERRA JGM; ALMEIDA DL; RIBEIRO R LD. 2005. Desempenho do consórcio entre repolho e rabanete com précultivo de crotalária, sob manejo orgânico. Horticultura Brasileira 23: 184-188.

OLIVEIRA NG; DE-POLLI H; ALMEIDA DL; GUERRA JGM. 2006. Plantio direto de alface adubada com cama de aviário sobre coberturas vivas de grama e amendoim forrageiro. Horticultura Brasileira 24: 112-117.

PAULA PD; GUERRA JGM; RIBEIRO RLD CESAR MNZ; GUEDES RE; POLIDORO JC. 2005. Rendimento agronômico do consórcio entre cebola e alface em sistema orgânico de produção. Seropédica-RJ: (Embrapa Agrobiologia, Recomendação técnica. 74), $4 \mathrm{p}$.

PORTES TA. 1984. Aspectos ecofisiológicos do consórcio milho x feijão. Informe Agropecuário 10: $30-34$.

REZENDE BLA; CANATO GHD; CECÍLIO FILHO AB. 2005a. Influencia das épocas de cultivo e do estabelecimento do consórcio na produção de tomate e alface consorciados. Ciência e Agrotecnologia 29: 77-83.

REZENDE BLA; CECÍLIO FILHO AB; CATELAN FC; MARTINS MIEG. 2005b. Análise econômica de cultivos consorciados de alface americana $x$ rabanete: um estudo de caso. Horticultura Brasileira 23: 853-858.

REZENDE BLA; CECÍLIO FILHO AB; FELTRIM AL; COSTA CC; BARBOSA JC 2006. Viabilidade da consorciação de pimentão com repolho, rúcula, alface e rabanete.
Horticultura Brasileira 24: 36-41.

SALA FC; COSTA CP. 2005. 'PIRAROXA: cultivar de alface crespa de cor vermelha intensa. Horticultura Brasileira 23:158-159.

SALGADO AS; GUERRA JGM; ALMEIDA DL; RIBEIRO RLD; ESPINDOLA JAZ; SALGADO JAA. 2006. Consórcios de alface-cenoura e alface-rabanete sob manejo orgânico. Pesquisa Agropecuária Brasileira 41: 1141-1147.

SANTOS RHS; GLIESSMAN SR; CECON PR. 2002. Crop interactions in broccoli intercropping. Biological Agriculture and Horticulture 20:51-75.

SUDO A; OLIVERA FL; GUERRA JGM; ALMEIDA DL; RIBEIRO RLD. 2001. Cultivo consorciado de alface e rabanete sob manejo orgânico. Seropédica-RJ: (Embrapa Agrobiologia, Recomendação técnica. 11), $4 \mathrm{p}$

TOLENTINO JÚNIOR CF; ZARATE HNA; VIEIRAMC. 2002. Produção de mandioquinhasalsa consorciada com alface e beterraba. Acta Scientiarum 24: 1447-1454.

TRENBATH BR. 1993. Intercropping for the management of pests and diseases. Field Crops Research 34: 381-405.

VIEIRA MC; ZÁRATE NAH; GOMES HE. 2003. Produção e renda de mandioquinha-salsa e alface, solteiras e consorciadas, com adubação nitrogenada e cama-de-frangos em cobertura. Acta Scientiarum 25: 201-208.

WILSON BJ. 1988. Shoot competition and root competition. Journal of Applied Ecology 25: 279-296.

ZONTA EP; SILVEIRA P; MACHADO AA. 1986. Sistema de análise estatística (SANEST). Pelotas: Instituto de Física e Matemática, UFPel. 399p. 